\title{
Efektifitas Program Partisipatif Kelompok Perempuan dalam Meningkatkan Swadaya Masyarakat
}

\section{Effectiveness of Women's Group Participative Program in Improve the Community's Self-help}

\author{
${ }^{1}$ Yeni M, ${ }^{2}$ Sartika Yuliana, ${ }^{3}$ Rini Parmila Yanti \\ Universitas Negeri Padang (UNP), Padang \\ rini sosiologunp@,yahoo.com
}

Riwayat Artikel: Dikirim 8 Oktober 2018; Diterima 28 November; Diterbitkan 30 November

\begin{abstract}
Abstrak
Di era otonomi daerah, yang diawali dengan UU RI No. 22 Tahun 1999, yang diamandemen dengan UU RI No. 32 Tahun 2004 tentang pemerintah lokal, telah memberikan kesempatan bagi otonomi daerah dan kesempatan-kesempatan untuk mengoptimalkan sumber daya-sumber daya yang ada di daerah guna kemakmuran dan kesejahteraan masyarakat, kemudian untuk merencanakan pembangunan sebagaimana diatur dalam UU No. 25 Tahun 2004 tentang sistem perencanaan pembangunan nasional. Produk hukum tersebut sekali lagi mengubah deadlock paradigm pembangunan dari atas ke bawah ke pembangunan berbasis masyarakat dari bawah ke atas, yang mana merupakan model dari pola pembangunan partisipatoris yang diterapkan di Kabupaten Sijunjung, yang melibatkan masyarakat dalam semua proses pembangunan. The purposes of the research conducted by the author are: 1) untuk mengetahui bagaimana program tersebut diimplementasikan di Desa Kunangan Parik Rantang, Kecamatan Kamang Baru, Kabupaten Sijunjung selama periode 2 tahun. 2) untuk menentukan bagaimana level pemerintahan Desa Kunangan Parik Rantang pada setiap pembangunan yang dilakukan melalui program partisipatoris. 3) untuk mengetahui bagaimana efektivitas program partisipatoris di Desa Kunangan Parik Rantang dalam upaya untuk meningkatkan program-program swadaya yang diterapkan melalui partisipatoris. Studi ini menggunakan pendekatan penelitian deskriptif dengan pendekatan kualitatif yang mana peneliti mencoba untuk menggambarkan seluruh gejala, kejadian, dan fenomena apa adanya dalam kaitannya dengan data dan informasi yang telah diperoleh dari responden (sumber data). Hal ini dilakukan secara konstan merujuk pada pembahasan isu-isu yang yang telah ditentukan sebelumnyya. Menurut Moloeng "penelitian kualitatif adalah prosedur penelitian yang memproduksi data dalam bentuk kata-kata - tertulis atau kata-kata yang diucapkan oleh orang - orang dan perilaku yang dapat diamati". Studi ini menunjukkan bahwa program pembangunan partisipatoris adalah program yang sangat efektif untuk meningkatkan kesadaran organisasi-organisasi pemerintahan akan pembangunan, karena program tersebut tidak hanya melibatkan masyarakat dalaam perencanaan, implementasi, dan monitoring pembangunan tetapi juga melibatkan masyarakat dalam pembiayaan pembangunan, dengan pola pembiayaan 30\% dibebankan kepada masyarakat dan $70 \%$ kepada pemerintah, dalam rangka meningkatkan rasa memiliki dari publik atas hasil-hasil pembangunan, yang pada akhirnya tanpa perintah, masyarakat akan berkontribusi pada hasil-hasil pembangunan tersebut. Program ini juga merupakan salah satu solusi bagi pemerintah daerah Sijunjung dalam mengatasi kurangnya dana yang tersedia untuk pembangunan di anggaran Kabupaten Sijunjung, oleh karena pola partisipatifnya bila dibandingkan dengan apa yang tender atau kontraktor lakukan akan mampu menyediakan dana sebesar 30,32\% untuk pelaksanaan pembangunan. Sayangnya, program ini tampak kurang mendapat dukungan dari kelompok elit - elit dan pemangku kepentingan di Kabupaten Sijunjung, dibuktikan dengan rendahnya dana yang dianggarkan oleh pemerintah lokal, yang hanya berkisar antara 0,5\% dan 0,7\% setiap tahunnya dari keseluruhan Anggaran dan Pengeluaran Kabupaten Sijunjung. Pemerintah maupun dewan di Sijunjung harus memiliki komitmen dan hasrat yang kuat untuk meningkatkan alokasi dana partisipatoris setiap tahun sebesar 1,5-2,0\%, dari total anggaran Kabupaten Sijunjung, yang sebesar 14-15 milyar rupiah per tahun. Komposisi pembiayaan pembangunan partisipatoris yang saat ini dibagi menjadi $70 \%$ pemerintah dan $30 \%$ kelompok masyarakat perlu dirubah menjadi 85\% pemerintah lokal dan 15\& kelompok masyarakat, sehingga komposisi penbiayaan partisipatif tidak terlalu membebani kelompok pengusul yang secara ekonomi lemah, dan mereka diharapkan untuk dapat langsung mengimplementasikan pengembangan ini melalui pola-pola partisipatoris.
\end{abstract}

Kata kunci: program partisipatif, kabupaten Sijunjung, masyarakat 


\begin{abstract}
In the era of regional autonomy, which starts from the regulations of Law Number 22 of 1999 as amended by Act Number 32 of 2004 concerning local government, has provided an opportunity for local autonomy and opportunities to optimize existing resources in the region for the prosperity and welfare of the people, then to plan the development of regulated law No. 25 Year 2004 concerning the system of national development planning, regulatory legal product is once again paved the deadlock top-down development paradigm into a folk-based development of bottom-up, the main approach to bottom-up models which is the model of participatory development patterns in Sijunjung Regency involving the community in the whole process of development. The purpose of the research conducted by the author are: 1) To find out how the program is implemented in village of KunanganParik Rantang, District of Kamang Baru, Sijunjung within a period of 2 Years. 2) To determine bow the level of Governmental village of Kunangan Parik Rantang in every development is carried out through a participatory program. 3) To know how Participatory Program Effectiveness in villages Kunangan Parik Rantang in an effort to improve the non-governmental development programs implemented through participatory. This study is a descriptive research method with qualitative approach, where researchers try to describe all the symptoms, events or phenomena as it is in accordance with the data and information that has been obtained from the respondents (data source), this is done by constantly referring to the discussion of issues that have been determined in advance, according Moloeng "qualitative research is a research procedure that produces a data description form of words - written or spoken words of people - people and behaviors that can be observed". This study shows that participatory development program is a program that is very effective in raising the awareness and governmental organizations to development, because the program does not only involve the community in the planning, implementation and monitoring of development, but also involving communities in development financing, with the pattern of charging 30\% community, and 70\% of Government, so as to increase the sense of public ownership of the results of development, which in the end without command will always keep the public with the results of such development. The program also is one of the solutions for local government Sijunjung, in overcoming the lack of funds available for development in the district budget Sijunjung, because the participative pattern when compared with the pattern of the tender or contractors did Sijunjung local governments, will be able to save funds to the implementation of a development of $30.32 \%$. Unfortunately, this program seems less a place in the hearts of the elite - the elite and stakeholders in Sijunjung Regency, evidenced by the lack of funds budgeted by the local government, which is only $0.5 \%$ to $0.7 \%$ annually of the total Budget and Expenditure of Sijunjung, to the District Government of Sijunjung together with parliament of Sijunjung must have a strong commitment and desire, to increase the allocation of funds participatory, every year to $1.5 \%$ up to 2.0\%, of the total budget Sijunjung, which Range between 14 to 15 billion annually. Participatory development funding composition, currently borne by the local government $70 \%$, and community groups proposer of $30 \%$, should be changed to $85 \%$ of local government and community groups proposing 15\%, so that the composition of participative funding, not overly burden the proposer group, which the economically weak, and they are expected to eventually be able to implement this development through participatory patterns.
\end{abstract}

Keywords: participative program, Sijunjung regency, community

\section{PENDAHULUAN}

Penyediaan dana hibah oleh Pemerintah Daerah Kabupaten Sijunjung, dalam bentuk Program Partisipatif sebagai perangsang pelaksanaan pembangunan di kabupaten Sijunjung, diharapkan akan mampu memberdayakan potensi yang ada pada masyarakat untuk merencanakan, melaksanakan dan melakukan pengawasan sendiri terhadap pelaksanaanpembangunan serta ikut merasa memiliki hasil-hasil pembangunan serta timbulnya keinginan untuk memelihara hasil-hasil pembangunan tersebut.

Adapun dasar pelaksanaan dari program partisipatif ini oleh Pemerintah daerah Kabupaten Sijunjung adalah Peraturan Menteri Dalam Negeri nomor
32 tahun 2011 tentang Pedoman pemberian hibah dan bantuan sosial yang bersumber dari anggaran pendapatan dan belanja daerah, dan dipertegas dengan Peraturan Bupati Sijunjung Nomor 10 Tahun 2012 tentang Petunjuk Teknis Operasional Bantuan Dana Program Partisipatif Kabupaten Sijunjung yang bertujuan:

1. Mendorong terciptanya peningkatan partisipasi masyarakat dalam pembangunan di Nagari.

2. Meningkatkan nilai tambah dan volume hasil hasil pembangunan akibat muncul nya partisipasi masyarakat dari setiap dana pembangunan yang dialokasikan. 
3. Mendorong terciptanya nilai-nilai kegotongroyongan pada masyarakat di Nagari.

4. Secara langsung meningkatkan kemam puan manajemen pengelolaan kegiatan pembangunan bagi kelompok-kelompok masyarakat baik perencanaan, pelaksanan, maupun pengelolaan administrasi dan teknis kegiatan pembangunan.

5. Menciptakan dan memperluas lapangan pekerjaan bagi masyarakat atas hasilhasil pembangunan, sekaligus meningktakan keinginan dan rasa tanggung jawab dalam pemeliharaan hasil pembangunan

Sementara itu sasaran dari program pembangunan partisipatif adalah untuk meningkatkan hasil dan nilai pembangunan yang dilandasi oleh kebutuhan dan partisipasi masyarakat dalam melaksanakan pembangunan di Kabupaten Sijunjung, dana bantuan program partisipatif ini diberikan kepada kelompok masyarakat untuk kegiatan pembangunan sarana dan prasarana fasilitas umum dan perekonomian masyarakat, seperti: Jalan dan jembatan, pendidikan, Kesehatan, olah raga, pengairan dan jalan usaha tani dalam rangka untuk meningkatkan kesejahteraan masyarakat.

Namun dalam implementasinya dilapangan, program ini juga mempunyai dampak positif dan negatif terhadap pelaksanaan percepatan pembangunan di kabupaten sijunjung.

Prosedur dan mekanisme untuk memperoleh bantuan dana melalui program partisipatif adalah sebagai berikut :

1. Kelompok masyarakat nagari yang berminat mendapatkan bantuan dana program partisipatif untuk membiayai kegiatan, mengajukan permohonan kepada Bupati Sijunjung Cq. Pokja Kabupaten yang diketahui oleh Wali Nagari dan disampaikan melalui Camat dengan melampirkan rencana kegiatan pembangunan yang akan dilaksanakan dan bagian kegiatan yang direncanakan dibiayai dari dana program partisipatif, Rencana kegiatan yang diusulkan diutamakan yang telah dibahas dalam Musrenbang Nagari pada tahun sebelumnya dan telah terrcantum dalam Rencana Pembangunan Jangka Menengah Nagari ( RPJMN) yang bersangkutan.

2. Bagi kelompok masyarakat yang mengajukan dana Program Partisipatif, membentuk panitia pembangunan yang ditetapkan dengan keputusan Wali Nagari dengan susunan yang terdiri dari Ketua, Sekretaris, Bendahara dan personil lainnya sesuai dengan kebutuhan serta diharapkan panitia ada dari unsur LPM Nagari.

3. Permohonan/Proposal dari kelompok masyarakat/Panitia Pembangunan dilampiri dengan:

a. Rencana Anggaran Biaya ( RAB ), Gambar Rencana serta foto $0 \%$ pada 3 titik lokasi yang berbeda

b. Hasil Rapat / Musyawarah kelompok yang diketahui oleh Wali Nagari

c. Surat Pernyataan kesanggupan swadaya masyarakat

d. Susunan organisasi kelompok masyarakat sebagai pelaksana ditetapkan dengan Keputusan Wali Nagari

e. Daftar hadir peserta rapat/Musyawarah yang dilegalisasi oleh Wali Nagari

f. Foto Copy KTP Ketua Pelaksana Kegiatan

g. RAB Kegiatan yang diketahui oleh Kepala Unit Pelaklsana Teknis Dinas Pekerjaan Umum Daerah

h. Dan Surat Penyerahan Lahan / Bukti kepemilikan Lahan yang terkena dampak Kegiatan

Pencairan dana di bagi dalam 3 tahap yakni tahap pertama $50 \%$, tahap Kedua $40 \%$ dan tahap ketiga $10 \%$

4. Jika dalam pelaksanaan pembangunan partisipatif pekerjaan tidak dapat diselesaikan oleh panitia pembangunan sesuai dengan RAB dan gambar rencana, maka ketua pembangunan akan diberikan teguran tertulis dan harus 
mengembalikan dana hibah ke kas daerah, senilai bobot pekerjaan yang tidak dapat dilaksanakan, dan bagi nagari yang bersangkutan tidak akan diberikan bantuan dana program partisipatif selama 2 (dua) tahun berturut-turut.

5. Evaluasi program bantuan dana partisipatif dilaksanakan dengan menggunakan indikator kinerja terhadap kegiatan pembangunan yang meliputi : input, output, hasil, manfaat dan dampak dari hasil kegiatan pembangunan yang dilaksanakan.

Sebagaimana yang kita ketahui bersama sesempurna apapun sistem yang telah disusun dalam perencanaan sebuah program, namun dalam impelementasinya pastilah akan banyak menimbulkan masalah-masalah, ini disebabkan para pelaku perencana pembangunan yang tidak teliti dan tidak menguasai sistim perencanaan pembangunan dengan baik, dan kurangnya sosialisasi terhadap masyarakat, seperti sangat minimya anggaran yang disediakan oleh Pemerintah Daerah Kabupaten Sijunjung untuk Program Partisipatif yang hanya kurang 1 (Satu) \% dari total APBD Kabupaten Sijunjung setiap tahunnya, juga sangat tingginya dana pendamping yang harus disediakan oleh kelompok masyarakat yang ingin mendapatkan program ini, yakni sebesar $30 \%$ dari total anggaran yang dibutuhkan dalam melaksanakan sebuah kegiatan pembangunan, serta masih rendahnya kepedulian masyarakat terhadap pembangunan, karena masih adanya pola pikir masyarakat yang menganggap pembangunan adalah kewajiban pemerintah, sedangkan masyarakat hanyalah sebuah onjek dari pembangunan.

Atas dasar pemikiran tersebut penulis termotivasi untuk mengetahui dan menganalisa secara lebih mendalam tentang program partisipatif ini di kabupaten sijunjung, dengan memilih judul penelitian "Efektivitas Program Partisipatif Kaum Perempuan dalam meningklatkan Swadaya
Masyarakat Untuk Pembangunan di Nagari Kunangan Parik Rantang Kabupaten Sijunjung".

\section{METODE}

Penelitian ini merupakan penelitian deskriptif dengan pendekatan kualitatif, dimana peneliti mencoba menggambarkan semua, gejala ataupun peristiwa atau fenomena secara apa adanya sesuai dengan data dan informasi yang telah diperoleh dari responden (sumber data), hal ini dilakukan dengan senantiasa mengacu pada pembahasan masalah yang sudah ditetapkan terlebih dahulu. Nana Sudjana dan Ibrahim (1989: 64) mengemukakan bahwa penelitian deskriptif adalah:

$$
\text { "Penelitian yang berusaha }
$$
mendiskripkan suatu gejala, peristiwa, kejadian yang terjadi saat sekarang dimana peneliti berusaha melihat peristiwa dan kejadian yang menjadi pusat perhatiannya untuk kemudian digambarkan sebagaimana adanya"

bahwa:

Moloeng (2007: 3) berpendapat

"Penelitian kualitatif adalah prosedur penelitian yang menghasilkan data deskripsi berupa kata - kata tertulis atau lisan dari orang - orang dan perilaku yang dapat diamati"

Sejalan dengan itu, Denzim dan Lincoln dalam Moloeng (2007: 5) mengatakan:

"Kualitatif adalah penelitian yang menggunakan latar alamiah dengan maksud menafsirkan fenomena yang terjadi dan dilakukan dengan jalan melibatkan berbagai metode yang ada" Metode deskriptif memusatkan perhatian pada masalah - masalah yang ada pada saat penelitian dilakukan dan masalah - masalah yang bersifat aktual. Secara ringkas cara yang dilakukan dalam penelitian ini adalah non eksperimental dan analisis yang digunakan adalah analisa deskriptif.

Pendeskripsian ini dilakukan dalam bentuk keterangan - keterangan ataupun infomasi, diupayakan untuk diterjemahkan dalam bentuk keterangan, untuk data dalam 
bentuk angka - angka dijadikan sebagai dasar analisis ataupun bahan untuk memperkuat pembahasan.

\section{Sasaran}

Sasaran kegiatan pengabdian kepada masyarakat adalah siswa kelas XII SMA NEGERI 1 Ampel. Metode kegiatan yang dilakukan dalam pengabdian masyarakat ini adalah dengan metode partisipatif artinya mitra binaan secara aktif dilibatkan semua dalam semua tahapan kegiatan pengabdian masyarakat ini.

\section{Tahapan Pelaksanaan}

Berangkat dari permasalahan yang muncul disusun berbagai alternatif untuk memecahkan masalah. Dari berbagai alternatif, dipilih alternatif yang paling mungkin dilaksanakan. Pelaksanaan kegiatan pengabdian ini dilaksanakan sebagai berikut:

\begin{tabular}{ccl}
\hline No & Tahapan & \multicolumn{1}{c}{ Kegiatan } \\
\hline 1 & Tahap I & $\begin{array}{l}\text { Persiapan : } \\
\text { perizinan, persiapan } \\
\text { bahan dan materi }\end{array}$ \\
\hline 2 & Tahap II & $\begin{array}{l}\text { Memberikan materi } \\
\text { pelatihan }\end{array}$ \\
\hline 3 & Tahap III & $\begin{array}{l}\text { Praktek strategi } \\
\text { pencarian informasi }\end{array}$ \\
\hline 4 & Tahap IV & $\begin{array}{l}\text { Evaluasi dan } \\
\text { tindaklanjut }\end{array}$ \\
\hline 5 & Tahap V & $\begin{array}{l}\text { Pelaporan hasil dan } \\
\text { publikasi }\end{array}$ \\
\hline
\end{tabular}

\section{Langkah-langkah}

Pengabdian ini dilaksanakan dengan metode ceramah dan evaluasi. Siswa mendengarkan pelatihan mengenai karakter taat dan memberikan pertanyaan kepada siswa terkait ketaatan yang dilakukan. Evaluasi dari kegiatan ini menekankan pada proses dan hasil. Penilaian proses dilakukan pada saat siswa mendengarkan ceramah. Melalui pertanyaan dan keseriusan siswa akan diperoleh bagaimana antusiasme dan kebermanfaatan kegiatan ini. Akan dievaluasi juga tentang pengetahuan siswa tentang pengalaman yang dilakukan siswa saat aktivitas belajar.

Kegiatan ini menggunakan metode pelatihan yang dilaksanakan selama 4 (empat) hari dengan materi pelatihan berupa pre-test, pelatihan materi (ceramah), post-test, serta evaluasi yang disajikan secara bersamaan. Setelah kegiatan pelatihan, akan dilanjutkan kegiatan evaluasi sebagai bahan koreksi bagi penyelenggara kegiatan. Hasil evaluasi ini nantinya dapat dijadikan sebagai bahan pertimbangan bagi perpustakaan untuk melaksanakan kegiatan serupa terkait dengan kegiatan pendidikan pemakai. Adapun penjabaran langkahlangkahnya sebagai berikut:

1. Analisis situasi dengan menyebar survey karakter taat kepada siswa

2. Persiapan pengabdian masyarakat meliputi perizinan, persiapan bahan dan materi

3. Pelatihan melalui presentasi menggunakan powerpoint untuk memberikan materi

4. Praktek strategi karakter taat melalui aktivitas belajar siswa

5. Monitoring dan evaluasi

6. Pelaporan hasil pelaksanaan kegiatan dan publikasi pengabdian masyarakat

Kegiatan pengabdian masyarakat ini meliputi empat kegiatan yaitu :

a. Memberikan post-test kepada siswa mengenai karakter taat melalui angket

b. Pelatihan melalui presentasi menggunakan powepoint untuk memberikan materi berupa karakter taat pada siswa untuk meningkatkan aktivitas belajar

c. Memberikan pre-test kepada siswa setelah diberikan pelatihan berupa karakter taat untuk meningkatkan aktivitas belajar melalui angket

d. Monitoring dan evaluasi yaitu kegiatan yang mem-follow up dari kegiatan yang pernah dilakukan sehingga pelaksana menemukan temuan-temuan yang dapat digunakan sebagai bahan pertimbangan/perbaikan ketika melaksanakan kegiatan pengabdian. 
HASIL DAN PEMBAHASAN

Program Partisipatif yang dilaksanakan di Nagari Kunangan Parik Rantang, Kecamatan Kamang Baru, Kabupaten Sijunjung dalam kurun waktu 3 (tiga) Tahun Terakhir

Selain upaya percepatan dan pemerataan pembangunan di nagari, pelaksanaan program partisipatif juga bertujuan menghidupkan kembali potensi budaya masyarakat untuk berperan aktif dalam pembangunan.

Oleh karena itu, pada tahun-tahun mendatang, program partisipatif perlu dilanjutkan dan dilaksanakan secara berkesinambungan, supaya pembangunan berbasis nagari yang didambakan Pemkab Sijunjung terwujud dan tercapai sesuai sasaran dan harapan.

Menurut Muchlis Anwar yang penulis wawancarai tanggal 21 Nopember 2014 mantan Kepala Bappeda Kabupaten Sijunjung menyatakan:

pola pembangunan partisipatif yang merupakan program strategis Kabupaten Sijunjung, telah dilaksanakan sejak tahun anggaran 2001.

Dalam rentang waktu 14 tahun (2001-2014), cukup banyak pembangunan prasarana dasar dan infrastruktur yang dituntas. Pembangunan yang hasilnya telah dirasa dan dinikmati masyarakat, mencakup di seluruh sektor. Seperti sarana dan prasarana perhubungan, irigasi, pasar, pendidikan serta sarana ibadah dan olahraga.

Karena merupakan upaya percepatan dan pemerataan, pembangunan yang seluruhnya bermuara kepada peningkatan ekonomi dan kesejahtraan rakyat, tidak saja terkonsentrasi di ibu kabupaten dan kecamatan, tapi merata di seluruh nagari.

Percepatan dan pemerataan pembangunan bisa tercapai, karena pelaksanaan program partisipatif diatur dengan Petunjuk Teknis Operasional (PTO) dalam bentuk keputusan bupati yang mengatur pelaksanaan dan pengelolaan serta mekanisme yang jelas dan ringkas serta dapat dipertanggungjawabkan. Secara umum tahapan pelaksanaan program partisipatif meliputi, sosialisasi kepada masyarakat, pengusulan proposal kegiatan lengkap dengan Rencana Anggaran Biaya (RAB) oleh masyarakat, penilaian kelayakan proposal dan RAB oleh kelompok kerja di lapangan serta tahap penyerahan bantuan kepada panitia pelaksana kegiatan.

Penggunaan dana yang sudah diatur dalam PTO, dicairkan dalam tiga tahap. Tahap pertama dana dicairkan 50 persen setelah proposal disetujui. Setelah dana yang diambil pada tahap pertama dapat dipertanggungjawabkan secara benar dan setelah pekerjaan pembangunan mencapai 50 persen, dicairkan dana tahap kedua 45 persen.

Sedangkan dana yang tersisa lima persen, dicairkan pada tahap ketiga setelah panitia pembangunan menyerahkan dan melengkapi Surat Pertanggungjawaban (SPj) penggunaan dana tahap pertama dan kedua yang juga dilengkapi dengan laporan pelaksanaan/berita acara serahterima pekerjaan.

Karena begitu ketat dan selektifnya penggunaan dana, berbagai sarana dan prasarana yang dituntaskan melalui program partisipatif, tidak saja mampu mempercepat dan pemerataan pembangunan, tapi hasilnya juga berlipat ganda, karena masyarakat nagari berperan aktif dalam mengerjakannya. Justru itu, tahun-tahun mendatang program ini perlu dianjutkan dan dilaksanakan secara berkesinambungan.

Seiring dengan kebutuhan masyarakat akan pola pembangunan yang partisipatif yang langsung menyentuh masyarakat, maka Pemerintah Daerah Kabupaten Sijunjung tahun ini melounching secara resmi program baru yang diberi nama P2BN (Program Pembangunan Partisipatif Berbasis Nagari) yang diatur dalam Peraturan Bupati Sijunjung No.14 Tahun 20011 dan tahun 
ini dialokasikan dana sebesar Rp.6 M. Dimana program ini sebagian besar mengadopsi pola PNPM yang diharapkan dapat memberikan motivasi kepada masyarakat sehingga pemberdayaan masyarakat yang di inginkan dapat terwujud,karena program ini dari, oleh dan untuk masyarakat.

Tujuan dari program ini adalah:

1. Meningkatkan partisipasi masyarakat dalam pelaksanaan pembangunan Nagari

2. Memberdayakan pemerintah nagari dalam pelaksanaan pembangunanNagari

3.Meningkatkan peran serta dan kerjasama antara masyarakat dan Pemerintah Nagari dalam upaya

peningkatan usaha ekonomi masyarakat serta penanggulangan kemiskinan

4. P2BN dilaksanakan dalam rangka membantu masyarakat untuk mendanai kebutuhan fisik sarana prasarana dalam usaha peningkatan ekonomi masyarakat serta pengentasan kemiskinan

Sarana/prasarana yang dapat dibantu:

a. Sarana/prasarana Jalan

b. Sarana/prasarana Irigasi

c. Sarana/prasarana Pertanian

d. Sarana/prasarana Perkebunan Rakyat

e. Sarana/prasarana Perikanan

f. Sarana/prasarana Peternakan

g. Sarana/prasarana ekonomi masyarakat

h. Usaha industri rumah tangga

i. Pasar Tradisional

Dengan Program ini diharapkan akan mampu membantu Masyarakat dalam peningkatan ekonomi dan peningkatan kesejahteraan masyarakat di KabupatenSijunjung.

\section{Kendala dalam pelaksanaan}

Di dalam pelaksanaan Pembangunan partisipatif banyak batu sandungannya .Artinya adalah dalam pembabgunan partisipatif seharusnya antara realita yang terjadi dengan yang kita inginkan adalah bagaimana kemudian masyarakat merasa memilki nagari sagat sederhana, meilihara dan melaksanakan pembangunan tersebut. Di dalam pelaksanaan pembangunan partisipatif di nagari Kunaqngan Parik Rantang maka tidak bisa kita pungkirri perlu ada yng namanya tahapan tahapan pelaksanaan dalam pembagunan di nagari. Bentuk Partisipasi Masyarakat dalam Pembangunan Nagari.

Pertama; Partisipasi masyarakat dalam tahapan ini merupakan kelanjutan dari proses perencanaan yang telah ditetapkan sebelumnya. Partisipasi masyarakat dalam tahapan pelaksanaan ini sebetulnya dapat dilihat sebagai sebuah sumbangan masyarakat baik dalam bentuk tenaga, uang maupun material yang diarahkan kepada jalannya program pembangunan. Kontribusi yang diberikan oleh masyarakat tersebut dapat dinilai sebagai sebuah indikator berpartisipasinya sebuah masyarakat.

Kedua; Partisipasi masyarakat pada bagian ini diartikan sebagai sebuah upaya yang dilakukan oleh masyarakat dalam menganalisa serta mencermati hasil program yang telah dilaksanakan, apakah telah sesuai dengan apa yang direncanakan atau tidak. Dengan demikian masyarakat dapat menilai kinerja yang telah dilakukan oleh pemerintahan nagari.

Ketiga; Sesuai dengan aspek yang diteliti, maka masyarakat juga dapat menilai apakah pembangunan benar-benar telah sesuai dengan yang diharapkan. Penilaian itu dapat berbentuk pemanfaatan oleh masyarakat terhadap hasil pembangunan. Bila tak dimanfaatkan dengan baik berarti tak sesuai dengan perencanaan dan penggalangan aspirasi yang dilakukan sebelumnya.

Hambatam dalam pembangunan partisipatif menurut wali nagari Kumanis Gogar Marajo; adalah kebijakan pemerintah terdahulu dalam pembangunan di nagari Kumanis tidak melibatkan masyarakat sehingga permasalahan gotong royong mulai pudar ini terjadi pada masa rezim Orde Baru. 
Artinya selama Orde Baru keputusan dan perencanaan berasal dari pusat jadi masyarakat hanya menerima apa yang telah di putuskan oleh pusat, ini yang kemudian di sebut dengan pembangunan Top Down (dari atas kebawah).

Jadi masyarakat sudah terbiasa menerima tugas atau instruksi dari atas jadi, ketika tidak ada instruksi dari atas maka partisipasi belum muncul kepermukaan dan ini mengalir sampai hari ini. Pembagunan partisipatif mencoba mengobati penyakit orde baru dengan cara melibatkan masyarakat dalam pembangunan. Jadi artinya masyarakat bawak di berdayakan dalam pembangunan partisipatif.

Namun kendala yang kita rasakan hari ini dalam pembangunan partisipatif adalah kurang kesadaran masyarakat artinya semangat individualisme semakin meroket sementara semangat kebersamaan turun dratis terbukti ketika diadakan gotong royong dalam pembangunan di nagari ternyata kurang kesadaran masyarakat untuk hadir.

Adapun Faktor penyebab terhambatnya partisipasi masyarakat dalam pembangunan di nagari.

- Belum ada satu kesepahaman konsep partisipasi oleh pihak perencana dan pelaksana pembangunan

- Faktor budaya masyarakat yang telah terlanjur dibangun pada pembangunan masa orde baru masyarakat pasif

- Manipulasi partisipasi masyarakat

- Minimnya kapasitas organisasi

- Kemungkinan munculnya konflik akibat perbedaan tuntutan dari warga

\section{Upaya mengatasi Kendala}

Partisipasi masyarakat merupakan suatu alat guna memperoleh informasi mengenai kondisi, kebutuhan, dan sikap masyarakat setempat, yang tanpa kehadirannya program pembangunan serta proyekproyek akan gagal; Masyarakat akan lebih mempercayai proyek atau program pembangunan jika merasa dilibatkan dalam proses persiapan dan perencanaannya, karena mereka akan lebih mengetahui seluk-beluk proyek tersebut dan akan mempunyai rasa memiliki terhadap proyek tersebut; ketiga, bahwa merupakan suatu hak demokrasi bila masyarakat dilibatkan dalam pembangunan masyarakat mereka sendiri.

Apa yang ingin dicapai dengan adanya partisipasi adalah meningkatnya kemampuan (pemberdayaan) setiap orang yang terlibat baik langsung maupun tidak langsung dalam sebuah program pembangunan dengan cara melibatkan mereka dalam pengambilan keputusan dan kegiatan-kegiatan selanjutnya dan untuk jangka yang lebih panjang. Adapun prinsipprinsip partisipasi tersebut:

1. Cakupan. Semua orang atau wakil-wakil dari semua kelompok yang ada di nagari ini, yang terkena dampak dari hasil-hasil suatu keputusan atau proses proyek pembangunan.

2. Kesetaraan dan kemitraan (Equal Partnership). Pada dasarnya setiap masyarakat nagari mempunyai keterampilan, kemampuan dan prakarsa serta mempunyai hak untuk menggunakan prakarsa tersebut terlibat dalam setiap proses guna membangun dialog tanpa memperhitungkan jenjang dan struktur masing-masing pihak.

3. Transparansi. Semua lembaga yang ada dinagari harus dapat menumbuhkembangkan komunikasi dan iklim berkomunikasi terbuka dan kondusif sehingga menimbulkan dialog.

4. Kesetaraan kewenangan (Sharing Power/Equal Powership). Berbagai pihak yang terlibat harus dapat menyeimbangkan distribusi kewenangan dan kekuasaan untuk menghindari terjadinya dominasi.

5. Kesetaraan Tanggung Jawab (Sharing Responsibility). Berbagai pihak mempunyai tanggung jawab yang jelas dalam setiap proses karena adanya kesetaraan kewenangan (sharing power) dan keterlibatannya dalam proses 
pengambilan keputusan dan langkahlangkah selanjutnya.

6. Pemberdayaan

(Empowerment). Keterlibatan berbagai seluruh unsur masyarakat yang ada dinagari Kunangan Parik Rantang ini tidak lepas dari segala kekuatan dan kelemahan yang dimiliki setiap pihak, sehingga melalui keterlibatan aktif dalam setiap proses kegiatan, terjadi suatu proses saling belajar dan saling memberdayakan satu sama lain.

7. Kerjasama. Diperlukan adanya kerja sama berbagai pihak yang terlibat untuk saling berbagi kelebihan guna mengurangi berbagai kelemahan yang ada, khususnya yang berkaitan dengan kemampuan sumber daya manusia.

Tingkat Swadaya Masyarakat Nagari Kunangan Parik Rantang dalam setiap pembangunan yang dilaksanakan melalui program partisipatif

Memperhatikan tabel 5 diatas, dapat dilihat bahwa swadaya masyarakat Nagari Kunangan Parik Rantang dalam pelaksanaan program partisipatif ini dapat dikatakan baik tapi belum seperti yang diharapkan yakni mencapai angka berimbang dengan biaya stimulan pemerintah.

Swadaya masyarakat merupakan modal utama dalam upaya mencapai sasaran program pemerintah diseluruh wilayah Republik Indonesia, Keberhasilan dalam pencapaian sasaran pelaksanaan program pembangunan bukan semata-mata didasarkan pada kemampuan aparatur pemerintah, tetapi juga berkaitan dengan upaya mewujudkan kemampuan dan keamanan masyarakat untuk berswadaya dalam pelaksanaan program pembangunan. Adanya swadaya masyarakat akan mampu mengimbangi keterbatasan Biaya dan kemampuan pemerintah dalam pencapaian pelaksanaan program pembangunan tersebut, Dalam konteks pelaksanaan pembangunan di Nagari Kunangan Parik Rantang Kabupaten Sijunjung swadaya masyarakat sangatlah penting guna membantu tercapainya pelaksanaan program pembangunan, sehingga akan timbul satu program dari prakarsa dan swadaya serta gotong royong dari masyarakat, Atas dasar inilah kesadaran dari masyarakat perlu terus di tumbuhkan dan ditingkatkan sehingga nantinya swadaya masyarakat akan dirasakan sehingga akan menjadi suatu kewajiban yang lahir secara spontan.

Berdasarkan hal di atas, berbagai hal diusahakan oleh pemerintah Daerah Kabupaten Sijunjung yaitu : penyediaan bantuan yang menunjang kegiatan masyarakat, perumusan kebijakan yang dapat memberikan kesempatan kepada masyarakat untuk turut serta dalam program pelaksanaan pembangunan. Pemberian kreatifitas, dan motivasi bagi tumbuhnya partisipasi masyarakat dalam pelaksanaan program pembangunan.

Dalam realitasnya, tidak semua anggota masyarakat di Nagari Kunangan Parik Rantang ikut berwadaya, dengan berbagai macam alasan.

Hal ini disadari karena adanya beberapa factor yang mempengaruhi. Disini diperlukan upaya untuk meyakinkan masyarakat tentang swadaya masyarakat dalam pembangunan, yaitu adanya komunikasi antara pemerintah dengan masyarakat atau sebaliknya. Keadaan seperti ini akan merubah sikap serta tindakan masyarakat yang selanjutnya menjadi dukungan untuk berswadaya.

Ini menunjukkan betapa besar peran pemerintah dalam meningkatkan swadaya masyarakat demi tercapainya pelaksanaan program pembangunan maksimal, Sebagai sarana swadaya masyarakat di nagari telah di bentuk lembaga-lembaga seperti Lembaga Pemberdayaan Masyarakat (LPM) Melalui lembaga ini masyarakat di harapkan dapat membantu mempercepat atau mengefektifkan pembangunan di Nagari dan Pembangunan Nasional pada Umumnya. 
Peningkatan swadaya masyarakat dalam pembangunan, di harapkan pada aspek keadilan dan pemerataan pembangunan serta hasil-hasil hendaknya pembangunan juga berorientasi pada kepentingan masyarakat yang betul-betul sesuai dengan apa yang di butuhkan dan dirasakan oleh mereka.

Pada saat ini pemerintah daerah kabupaten sijunjung hanya menganggarkan dana hibah untuk program partisipatif ini sbesar 0,5\% sampai dengan 0,7\% setiap tahunnya dari total APBD Kabupaten Sijunjung, yang besarannya berkisar antara 4 milyar sampai dengan 5 milyar setiap tahunnya.

Melihat dari besaran APBD Kabupaten Sijunjung Tahun 2013 dan 2014 yang masing - masing berjumlah Rp 659 Milyar dan Rp 717 Milyar, maka rasanya tidak lah akan terlalu membebani daerah apabila dana hibah untuk program partispatif ini ditingkatkan menjadi 1,5\% sampai dengan $2 \%$ setiap tahunnya dari total APBD Kabupaten Sijunjung, apabila ini bisa diwujudkan maka kabupaten sijunjung bisa menganggarkan dana hibah guna program partisipatif sebesar lebih kurang Rp 14 milyar setiap tahunnya.

Namun keinginan ini sepertinya tidak terlalu mendapatkan respon yang positif dari elit-elit di kabupaten sijunjung terutama pihak eksekutif dan legeslatif, karena mereka berfikaran program ini nantinya akan dapat mengecilkan kepentingan mereka dalam proses pembangunan dikabupten sijunjung, karena saat ini di kabupaten sijunjung ada 3 (tiga) pola perencanaan pembangunan yang digunakan untuk menyusun kegiatankegiatan pembangunan yang akan dilaksanakan di Kabupaten yaitu:

1. Perencanaan Teknoratis, yakni perencanaan pembangunan yang dirumuskan oleh Bupati beserta Satuan Kerja Perangkat Daerah ( SKPD) yang ada.

2. Perencanaan Politis, Yakni perencanaan pembangunan yang dirumuskan oleh angota dewan perwakilan rakyat ( DPRD ) Kabupaten sijunjung yang lebih dikenal dengan nama dana sinergi yang besarannya saat ini mencapai 1 milyar per anggota.

3. Perencanaan Partispatif, yakni perencanaan yang dilaksanakan secara reguler melalui Rembug Jorong, Musrembang Nagari, Musrenbang Kecamatan dan Musrenbang Kabupaten.

Apabila seluruh elit yang ada dikabupaten sijunjung mempunyai visi yang sama dalam memajukan daerah dan nagari yang ada dikabupaten sijunjung, maka sudah saatnya mereka mendukung penuh program pembangunan, seperti program pembangunan partisipatif ini, karena disamping program ini dapat menghemat anggaran yang hampir mencapai $30 \%$, program ini juga dapat membuka lapangan kerja bagi masyarakat.

Bila sistem dan prosedur musyawarah nagari berlangsung dalam suasana kondusif; proses musyawarah difasilitasi secara efektif oleh fasilitator yang paham metodologi; keterlibatan aparat pemerintah tidak dominan; hasilnya merupakan formulasi yang dapat diterima oleh mayoritas anak nagari, maka diharapkan sudah ditemukan suatu format perencanaan/ skenario pembangunan ekonomi berbasis partisipasi seluruh komponen nagari. Sebuah modal yang kuat untuk menindaklanjuti pengembangan ekonomi seperti dimaksud diatas.

Bila kebijakan umum pembangunan ekonomi nagari secara prinsip sudah disepakati oleh seluruh komponen nagari, maka soal selanjutnya adalah bagaimana memulai dan darimana harus melangkah. Mengingat potensi nagari ada di rantau dan di nagari, maka idealnya adalah menghadirkan sebuah Tim Fasilitator Partisipasi (selanjutnya disebut Tim) untuk memandu nagari dalam fase inisiasi dan transisional. Katakanlah suatu tim yang terdiri dari 5 orang sarjana (dengan berbagai latar belakang) dengan kualifikasi 
profesional LSM yang dilekatkan kedalam aktifitas pembangunan ekonomi nagari.

Tim yang memiliki kapasitas pengorganisasian; kemampuan metodologis menggerakkan partisipasi, mampu memandu penyusunan skenario pengembangan; memiliki akses ke berbagai pihak yang dapat mendukung pembangunan nagari (propinsi, nasional dan internasional) dan memiliki visi global serta khususnya berkemampuan teknis di bidang teknologi informasi. Tahapan kerja Tim dapat berupa:

Tim akan bekerja untuk mengkuantifikasi potensi yang dimiliki nagari (SDA, SDM, Teknologi) dan bekerja efektif mengembangkan skenario sinergi berbagai potensi itu bagi manfaat ekonomi maksimal anak nagari. Dapat dimulai dengan menghitung aset nagari berupa lahan ulayat, hutan nagari, sumber daya air, pasar nagari, sarang burung layang-layang, ulayat yang "dipinjamkan" kepada pemerintah/investor, dan berbagai aset lainnya. Selanjutnya tim bekerja menyusun rancangan usaha/business plan berdasarkan keunggulan potensi setempat yang akan dikonsultasikan dalam musyawarah nagari untuk disempurnakan serta segera dapat diterapkan.

Berdasarkan business plan Tim bekerja menginisiasi berbagai kelompok masyarakat (misalnya kelompok tani dsb.) dengan berangkat dari penyadaran dan skenario pembangunan ekonomi nagari. Idealnya seluruh anak nagari yang dikampung terlibat penuh dalam berbagai kelompok usaha yang diminatinya.

Tim juga dapat bekerja menyusun usulan "ulayat nagari baru" berupa kepemilikan HGU yang diajukan kepada pemerintah atau merekomendasikan penetapan ulayat khusus bagi pengembangan ekonomi nagari (misalnya ulayat kelautan, dimana 500 mil persegi dikelola oleh anak nagari dengan kaidah pengelolaan laut berbasis komunitas nagari).
Berdasarkan basis potensi dan peluang bisnis nagari, Tim bekerja mengembangkan berbagai kelembagaan usaha nagari berbasis kelompok-kelompok yang sudah dibentuk sebelumnya. Institusionalisasi ini kelak akan bermuara ke bentuk Koperasi Nagari sesuai hakikat basis ekonomi komunal partisipatif. Namun dapat pula berkembang dengan memiliki berbagai anak usaha mengurus bisnis spesifik yang sifatnya perseroan dimana koperasi nantinya berubah peran menjadi perusahaan induk/ holding company.

\section{Upaya mengatasi kendala}

Bila selama ini untuk memperoleh stabilitas bagi ketenangan dalam membangun adalah diberlakukannya kontrol terhadap massa mengambang hasil proses depolitisasi, maka antitesanya adalah diterapkan pendekatan konsientisasi/ penyadaran politik (politisasi yang positif), memberi peluang bagi terciptanya pengorganisasian masyarakat secara murni (tidak direkayasa dari atas untuk alasan apapun) serta lebih dibukanya semangat independesi/otonomi sebagai jawaban.

Kesadaran rakyat (termasuk kesadaran politis) akan problema yang dihadapi dalam membangun, ditimpali oleh terbukanya peluang mengekspresikan kreatifitas/inovasi berkat otonomi yang tercipta niscaya akan menghadirkan prakarsa-prakarsa masyarakat untuk berpartisipasi. Bila prakarsa telah berkembang, pemahaman akan keterbatasan yang dihadapi dalam melanjutkan pembangunan akan menghadirkan pula secara sadar semangat swadaya ditengah masyarakat. Kadar swadaya inilah yang menjadi bagian kontribusi riel dari masyarakat, bahu membahu bersama pemerintah menundukkan tantangan pembangunan.

Pandangan seperti ini tampaknya antitesa dari pendekatan makro pertumbuhan terpusat yang dominan dalam etappe pembangunan versi orde baru, karena prakarsa dan semangat swadaya 
tidak lagi sepenuhnya memerlukan mekanisme pasar dalam memperoleh sumberdaya pembangunan. Ia tidak lagi harus tunduk kepada ekspansi modal besar, cukup modal kecil untuk kebutuhan yang secara realistis juga kecil. Small is beautiful menurut Schumacher. Investasi lebih mendahulukan kepentingan orang banyak, memberi dampak ekonomi yang adil dan merata kepada segenap lapisan rakyat (bukan orang seorang!).

Pilihan usahanyapun tidak selalu berskala besar, sehingga tidak harus memerlukan modal patungan, serta menggantungkan diri pada ekonomi global. Produk yang diolahpun lebih diprioritaskan kepada pemenuhan kebutuhan dasar yang menyangkut hajat orang banyak. Keunggulan komparatif tidak lagi perlu ditawar-tawarkan, apalagi buruh murah harusnya menjadi tabu dan jelas tidak manusiawi untuk dijajakan kepada pemodal asing. Pasar internal menjadi tujuan utama dalam memutar ekonomi nasional. Itu artinya pasar dengan sekitar 250 juta konsumennya.

Industri yang menyangkut hajat nasional kepemilikannya haruslah mencerminkan pemerataan keuntungan kepada banyak pihak, dikuasai oleh rakyat sebagai pemilik dominan. Etika bisnis disini benar-benar cerminan dari konstitusi. Sementara itu industri yang berorientasi eksport barulah boleh dikelola secara apa yang kita amati menjadi trend dalam dunia industri kita belakangan ini. Konglomerat sebaiknya beroperasi pada lahan industri non-kebutuhan nasional agar tidak menimbulkan ekses keresahan nasional. Usaha besar silahkan berinvestasi di sektor manufaktur dan selamat berkompetisi dalam persaingan global. Stop segala praktek pembangunan yang tidak pro harkat manusia. Hentikan ekspansi pemodal besar yang sekedar meraup keuntungan dan jelas-jelas kurang memiliki etika kerja pro rakyat, pro kemanusiaan.

Menyambut pola baru era otonomi seluas-luasnya ini, pemerintah harus serius membangun image baru yang lebih membuka peluang maksimal bagi partisipasi masyarakat. Dampak luas dari pola ini diharapkan akan menumbuhkan semangat kemandirian, keswadayaan, melanjutkan pembangunan atas upaya dan kemampuan sendiri melalui aktifitas nyata. Makanya, segera saja memulai proses pendekatan pembangunan dari bawah (bottom-up development approach) yang sejauh mungkin melibatkan partisipasi aktif dari semua unsur masyarakat yang berkepentingan (people-centered development) serta dilaksanakan dengan cara-cara yang dapat menumbuhkan swadaya masyarakat setempat untuk kelak mampu mengatasi masalah dan memenuhi kebutuhan mereka sendiri.

Dalam pendekatan pembangunan yang partisipatif, upaya pemerataan dan faktor partisipasi kelompok masyarakat untuk mengembangkan swadaya mereka merupakan syarat utama. Pengolahan sumber daya alam, pengelolaan sumber daya manusia dan pemanfaatan teknologi "yang sesuai" dengan kemampuan dan kebutuhan masyarakat adalah bagian strategis yang harus dikembangkan/ didayagunakan.

Persoalannya kini adalah bagaimana memulainya serta sejauh mana kesiapan diperlukan. Ditengah dinamika yang birokratik, instruktif dan sentralistis sekarang ini, agaknya kita memerlukan energi ekstra dalam melakukan "enforcement", membalikkan sikap dan perilaku seluruh komponen pembangunan ( mental switch ).

Efektifitas Program Partisipatif di Nagari Kunangan Parik Rantang dalam upaya meningkatkan swadaya masyarakat untuk pembangunan yang dilaksanakan melalui program partisipatif

Program pembangunan partispatif adalah program yang sangat efektif dalam meningkatkan kepedulian dan swadaya masyarakat terhadap pembangunan, karena 
program ini tidak hanya melibatkan masyarakat dalam perencanaan, pelaksanaan dan pengawasan pembangunan, namun juga melibatkan masyarakat dalam pembiayaan pembangunan, dengan pola pembebanan biaya $30 \quad \%$ Masyarakat dan $70 \quad \%$ Pemerintah, sehingga dapat meningkatkan rasa memiliki masyarakat terhadap hasilhasil pembangunan, yang pada akhirnya tanpa dikomando masyarakat dengan senantiasa akan menjaga hasil-hasil pembangunan tersebut, dan juga program Partisipatif adalah salah satu solusi bagi pemerintah daerah kabupaten sijunjung, dalam mengatasi minimnya dana untuk pembangunan yang tersedia di APBD Kabupaten Sijunjung, karena dengan pola partispatif bila dibandingkan dengan pola tender ( dikerjakan oleh kontraktor) maka pemerintah daerah kabupaten sijunjung, akan dapat menghemat dana guna pelaksanaan sebuah pembangunan sebesar $30,32 \%$.

Selain itu untuk mengembangkan dan melembagakan swadaya masyarakat dalam pembangunan harus diciptakan perubahan suatu persepsi pemerintah dalam pembangunan serta untuk membangkitkan partisipasi masyarakat dalam pembangunan diperlukan sikap toleransi dari aparat pemerintah terhadap kritik yang diberikan oleh masyarakat karena kritik merupakan salah satu bentuk dari pertisipasi masyarakat.

Terkait dengan strategi pendukung untuk mengatasi permasalahan pembangunan nagari maka pengembangan peran partisipasi masyarakat sangat diperlukan terutama dalam mengidentifikasi permasalahan pembangunan yang ada sehingga nantinya pembangunan yang akan dilaksanakan benar-benar merupakan kebutuhan dari masyarakat, ada dua alasan utama mengapa partisipasi masyarakat mempunyai arti penting dalam pembangunan nagari yaitu:

1. Swadaya masyarakat merupakan suatu alat guna memperoleh informasi mengenai kondisi, kebutuhan, dan sikap masyarakat setempat

2. Masyarakat akan lebih mempercayai proyek atau program pembangunan jika mereka dilibatkan dalam proses perencanaan dan pelaksanaan

$$
\text { Strategi pembangunan nagari }
$$

adalah peningkatan kapasitas dan komitmen masyarakat untuk terlibat dan berpartisipasi dalam pembangunan, swadaya masyarakat secara langsung dalam tiap tahap proses pembangunan adalah merupakan ciri utama pembangunan nagari yang ideal.

Dalam proses pembangunan swadaya masyarakat berfungsi sebagai masukan dan keluaran, proses partisipasi dapat diklasifikasikan menjadi 6 tahap yaitu mulai dari penerimaan informasi, pemberian tanggapan terhadap informasi, perencanaan, pelaksanaan, penelitian, dan penerimaan kembali hasil. Pembangunan sebagai input atau masukan pembangunan disini diharapkan dengan adanya swadaya masyarakat bisa menumbuhkan kemampuan masyarakat untuk berkembang secara mandiri sedangkan sebagai output atau keluaran partisipasi merupakan proses keluaran stimulasi atau motivasi melalui berbagai upaya.

Untuk meningkatkan swadaya masyarakat dalam pembangunan maka dapat digunakan kerangka konsep sebagai berikut:

1. Swadaya masyarakat perlu dikembangkan dengan pola prosedural yaitu masyarakat atau kelompok sasaran diharapkan berperan serta aktif pada berbagai tahap dalam proses aktifitas pembangunan ekonomi.

2. Upaya meningkatkan kesadaran, kemauan, dan kemampuan golongan miskin untuk berswadaya. Hal ini dimaksudkan agar mereka berpartisipasi dan bias menolong perekonomian diri sendiri.

3. Program-program pembangunan sosial ekonomi yang hendak dikembangkan perlu diperhatikan. 
4. Keterlibatan agen pembaharuan dari luar komunitas hanya sejauh memberikan dorongan dan membantu memudahkan atau partisipasi warga masyarakat dan bukan berperan sebagai pelaku utama.

5. Swadaya masyarakat perlu dilaksanakan melalui lembaga-lembaga yang sudah dikenal atau kelompok yang dibentuk dari prakarsa warga masyarakat.

Apabila kerangka konsep swadaya masyarakat dalam pembangunan nagari seperti diatas dapat diterapkan maka diharapkan dapat mewujudkan tujuan dari pembangunan nagari, dengan terwujudnya tujuan pembangunan nagari selanjutnya diharapkan dapat meningkatkan kesejahteraan masyarakat.

Dalam Pembukaan UndangUndang Dasar 1945 dinyatakan bahwa tujuan Pembangunan Nasional Bangsa Indonesia adalah melindungi segenap bangsa dan seluruh tumpah darah Indonesia, memajukan kesejahteraan umum, mencerdaskan kehidupan bangsa, serta ikut melaksanakan ketertiban dunia, Untuk mewujudkan tujuan tersebut dilaksanakan pembangunan nasional, yaitu pembangunan manusia Indonesia seutuhnya dan pembangunan masyarakat seluruhnya.

Dalam merealisasikan tujuan pembangunan, maka segenap potensi alam harus digali, dikembangkan, dan dimanfaatkan sebaik-baiknya. Begitu pula dengan Potensi manusia berupa penduduk yang banyak jumlahnya harus ditingkatkan pengetahuan dan keterampilannya sehingga mampu menggali, mengembangkan dan memanfaatkan potensi alam secara maksimal, dan pelaksanaan program pembangunan tercapai.

Berbagai rencana dan programprogram pembangunan sebagai wujud pelaksanaan pemerintahan telah dibuat dan diimplementasikan di daerah dan kecamatan,baik yang dilaksanakan oleh pemerintah pusat melalui Instansi-instansi vertikal di daerah,maupun pemerintah daerah itu sendiri. salah satu program pemerintah daerah kabupaten sijunjung adalah program pembangunan partsispatif yaitu pembangunan yang dilaksanakan oleh masyarakat secara swadaya dan dibantu dengan dana hibah oleh pemerintah daerah, atau oleh lembaga-lembaga nonpemerintah lainnyayang memiliki programprogram pembangunan berupa pemberdayaan masyarakat.

Dalam mewujudkan tujuan program pembangunan pada setiap lembaga dibutuhkan suatu pola manajerial dalam pengelolaan pembangunan, pola manajerial tersebut dimaksudkan agar hasil pembangunan dan program-program pemerintahan lainnya dapat dirasakan dan dinikmati manfaatnya oleh masyarakat. Salah satu hal yang dibutuhkan adalah kesadaran dan partisipasi aktif dari seluruh masyarakat dalam menunjang suksesnya pelaksanaan program pembangunan. Selain itu juga diperlukan kebijaksanaan pemerintah untuk mengarahkan serta membimbing masyarakat untuk bersamasama melaksanakan program pembangunan.

Pembangunan merupakan suatu orientasi dalam kegiatan usaha tanpa akhir, pembangunan bukan berarti peningkatan pendapatan masyarakat saja namun pembangunan merupakan suatu proses multidimensi yang meliputi proses reorganisasi dan pembaharuan seluruh sistem serta aktivitas dalam hal ekonomi dan sosial dengan tujuan mensejahterakan kehidupan masyarakat.

Indonesia merupakan negara yang luas wilayahnya dimana sebagian besar wilayah Indonesia adalah pedesaan, maka dapat dikatakan bahwa pembangunan nagari / desa memiliki peran penting dalam terwujudnya pembangunan nasional secara lebih merata.

Pembangunan nagari / desa memiliki arti penting karena sebagian besar penduduk Indonesia bertempat tinggal dinagari / desa dan menggantungkan hidupnya dinagari / desa, pembangunan 
nagari ditujukan agar penduduk bukan hanya mampu memenuhi kebutuhanya sendiri tetapi juga mampu menggali segala potensi sumber daya yang ada dinagari untuk kemudian dimanfaatkan menjadi sesuatu yang lebih berharga.

Dalam pembangunan nagari partisipasi atau keterlibatan masyarakat sangat dibutuhkan dalam usaha terselenggaranya pembangunan, partisipasi masyarakat didasarkan atas kemauan diri sendiri artinya masyarakat nagari ikut serta dalam pembangunan atas dasar keyakinan dan kesadaran yang datang dari dalam diri mereka sendiri.

Agar upaya pembangunan nagari memenuhi apa yang diinginkan maka diperlukan suatu perencanaan, penerapan perencanaan pembangunan harus bersumber pada prinsip dasar pembangunan daerah yaitu dari, oleh, dan untuk masyarakat daerah itu sendiri. Oleh karean hal tersebut diperlukan kemampuan masyarakt untuk mengenali dan memecahkan segala permasalahan yang ada didalam wilayah tersebut serta dapat menggali potensi-potensi yang ada untuk selanjutnya dimanfaatkan dalam kegiatan pembangunan.

Permasalahan pembangunan nagari berhubungan dengan partisipasi ketenagakerjaan, akses dan kesempatan kerja terhadap faktor produksi serta informasi yang berkaitan dengan pasar.

Dari permasalahan seperti itulah kemudian berkembang menjadi beberapa pokok permaslahan dalam pembangunan nagari sebagai berikut:

1. Kemiskinan, pembangunan bertujuan untuk mengentaskan rakyat dari kemiskinan. Upaya penghapusan kemiskinan di Indonesia mengalami kesulitan karena berbagai factor seperti krisis ekonomi.

2. Kesenjangan pada pendapatan masyarakat, para penduduk nagari yang mayoritas berprofesi sebagai petani memiliki kesenjangan dalam hal pendapatan dimana petani miskin atau petani yang memiliki kebun/sawah tidak terlalu luas akan semakin menurun sedangkan petani yang memiliki modal kuat akan semakin kaya.

3. Kegagalan transformasi, akibat dari strategi industrialisasi yang tidak terencana dan terarah dengan baik dan mengabaikan sector pertanian maka keuntngan dari pertanian akan semakin menurun seiring dengan kenaikan harga produksi dan biaya hidup yang tidak cukup diimbangi dengan perolehan hasil panen.

4. Merosotnya kelembagaan lokal pada masyarakat nagari, terjadinya pergeseran nilai dan norma dalammasyarakat nagari serta terjadinya pergeseran persepsi dari masyarakat dalam memandang alokasi sumber daya karena adanya pengaruh dari mekanisme pasar.

Dari begitu banyaknya permasalahan dalam pembangunan nagari maka diperlakukan suatu strategi untuk mengatasinya, strategi dasar yang dilakukan dalam pembuatan kebijakan adalah pembangunan yang diarahkan seminimal mungkin terjadinya kesenjangan antara lain dengan mengurangi jumlah pengangguran yang ada.

Selain strategi dasar tersebut maka perlu adanya strategi pendukung dalam mengatasi masalah pembangunan nagari yaitu dengan pembangunan infrastruktur yang meliputi pendidikan dan infrastruktur lainnya serta pelibatan masyarakat dalam pembangunan.

Pembangunan pada dasarnya bertujuan untuk memberikan kehidupan yang lebih makmur dan sejarhtera bagi masyarakat, dalam upaya pembangunan partisipasi masyarakat mempunyai peran yang sangat penting karena pembangunan ditujukan untuk memenuhi kebutuhan dari masyarakat itu sendiri dan dengan adanya peran paertisipasi masyarakat dalam prose pembangunan diharapkan hasil dari pembangunan sesuai dengan apa yang 
diharapkan dan dibutuhkan oleh daerah tersebut. Partisipasi masyarakat sebagai strategi pendukung dalam mengatasi permasalahan pembangunan nagari sangatlah penting peranannya, seperti kerjasama antara masyarakat dengan pemerintah dalam merencanakan, melaksanakan, dan membiayai pembangunan.

\section{KESIMPULAN}

Berdasarkan apa - apa yang telah penulis coba uraikan diatas, maka penulis berkesimpulan bahwa:

1. Program Partisipatif yang dilaksanakan di Nagari Kunangan Parik Rantang, Kecamatan Kamang Baru, Kabupaten Sijunjung telah terlaksana beberapa tahun terakhir namun dana tersebut belum dirasakan oleh jorong-jorong dalam nagari Kunangan parik Rantang secara merata. Dalam kurun waktu 2 ( Dua ) Tahun Terakhir.

a. Terdiri dari 6 (enam) Kegiatan yang mencakup segala bidang pembangunan yakni, Bidang Sosial Budaya, Bidang Fisik dan Prasarana Serta Bidang Ekonomi.

b. Hanya dapat dilaksanakan oleh kelompok-kelompok masyarakat yang berekonomi baik

c. Dana pembangunan yang dilaksanakan melalui program partisipatif masih sangat rendah, bila dibandingkan dengan dana yang berasal dari APBN dan APBD

2. Tingkat Swadaya Masyarakat Nagari Kunangan Parik Rantang dalam setiap pembangunan yang dilaksanakan melalui program partisipatif.

a. Swadaya masyarakat untuk setiap kegiatan pembangunan melalui pola partispatif cukup tinggi sesuai yang syaratkan dalam program

b. Swadaya Masyarakt ini dapat mengurangi beban APBD Kabupaten Sijunjung dalam melaksanakan pembangunan di setiap Nagari karena dengan pola partispatif bila dibandingkan dengan pola tender ( dikerjakan oleh kontraktor) maka pemerintah daerah kabupaten sijunjung, akan dapat menghemat dana guna pelaksanaan sebuah pembangunan sebesar 30,32\%.

3. Efektifitas Program Partisipatif di Nagari Kunangan Parik Rantang dalam upaya meningkatkan swadaya masyarakat untuk pembangunan yang dilaksanakan di nagari Kunangan belum mencapai angka perimbangan antara dana stimulan pemerintah dengan nilai partisipasi masyarakat

a. Program pembangunan partispatif adalah program yang sangat efektif dalam meningkatkan kepedulian dan swadaya masyarakat terhadap pembangunan, tapi belum menyentuh seluruh daerah dalam nagari Kunangan Parik Rantangs

b. Komposisi pembiayaan dalam program partsipatif yang mengharuskan Masyarakat menyediakan dana swadaya sebesar $30 \%$ dari total dana yang dibutuhkan dalam pelaksanaan sebuah pembangunan, terkadang dirasakan berat oleh masyarakat, sehingga program ini hanya bisa didapatkan oleh kelompokkelompok masyarakat yang mampu menyediakan dana swadaya sebesar $30 \%$, bagi kelompok-kelompok masyarakat yang tidak mampu menyediakan dana swadaya sebagaimana dimaksud maka mereka tidak akan pernah mendapatkan program ini.

\section{DAFTAR PUSTAKA}

Arief Budiman, (2005) Teori Pembangunan Dunia Ketiga, Gramedia.

Gie, The Liang. (1993). Efesiensi Kerja Bagi Pembangunan Negara. Yogyakarta, Gadjah Mada University, Press. 
Koeswara, E. (2001). Otonomi Daerah : Untuk Demokrasi dan Kemandirian Rakyat. Jakarta, PT. Sembrani Aksara Nusantara.

Lembaga Administrasi Negara. (2001). Inventarisasidan Kajian tentang Kelembagaan Aparatur Pemerintah Pusat dan Daerah.

Ndraha, Hadari. (1993). Pengembangan Teori Pengembangan Sumberdaya Manusia. Jakarta, Rineka Cipta.

Nurmadi, Achmad. (1999). Manajemen Kota. Yogyakarta, Penerbit Sinergi Publishing.

Undang-Undang Nomor 32 Tahun 2004 tentang Pemerintahan Daerah.

Undang-Undang Nomor 25 Tahun 2004 tentang sistim perencanaan pembangunan nasional (SPPN).

Permendagri Nomor 32 Tahun 2011 tentang Pedoman pemberian hibah dan bantuan sosial yang bersumber dari APBD.

Peraturan Daerah Sumatera Barat Nomor 9 Tahun 2000, Tentang Ketentuan Pokok Pemerintahan Nagari.

Peraturan Daerah Sumatera Barat Nomor 22 Tahun 2001 Pemerintahan Nagari.

Peraturan Bupati Sijunjung Nomor 10 tahun 2012 tentang Petunjuk teknis operasional (PTO) Bantuan Dana Program Partispatif Kabupaten Sijunjung. 